\title{
Vibrio marisflavi sp. nov., isolated from seawater
}

Correspondence

Xiao-Hua Zhang

xhzhang@ouc.edu.cn

\author{
Hong Wang, Jiwen Liu, Yan Wang and Xiao-Hua Zhang
}

Department of Marine Biology, Ocean University of China, 5 Yushan Road, Qingdao 266003, PR China

\begin{abstract}
A Gram-reaction-negative, facultatively anaerobic bacterial strain, designated $\mathrm{WH} 134^{\top}$, was isolated from a seawater sample collected at a depth of $10 \mathrm{~m}$ near the Yellow Sea Cold Water Mass (YSCWM), $31^{\circ} 59.970^{\prime} \mathrm{N} 123^{\circ} 0.157^{\prime} \mathrm{E}$, PR China. Cells of strain WH134${ }^{\top}$ were slightly curved rods, motile by means of a polar flagellum and positive for poly- $\beta$-hydroxybutyrate (PHB) accumulation. The strain was able to grow in $1-6 \%(\mathrm{w} / \mathrm{v}) \mathrm{NaCl}$, at $\mathrm{pH} 5-10$ and $16-37{ }^{\circ} \mathrm{C}$ but not at 4 or $40{ }^{\circ} \mathrm{C}$. The major cellular fatty acids were summed feature $3 \mathrm{C}_{16: 1} \omega 7 \mathrm{c}$ and/or iso$\mathrm{C}_{15: 0} 2-\mathrm{OH}, \mathrm{C}_{16: 0}, \mathrm{C}_{18: 1} \omega 7 c, \mathrm{C}_{18: 0}$ and $\mathrm{C}_{14: 0}$. The DNA G+C content was $42.5 \mathrm{~mol} \%$. Phylogenetic analyses based on $16 \mathrm{~S}$ rRNA, gyrB, topA, recA, fts $Z, m r e B$, gap $A$ and rpo $A$ gene sequences revealed that strain $\mathrm{WH} 134^{\top}$ belongs to the genus Vibrio and showed gene sequence similarities of $96.6,75.7,74.6,83.6,78.9,82.9,86.0$ and $89.4 \%$, respectively, to Vibrio rumoiensis $\mathrm{S}-1^{\top}$. The possession of a flagellum, activity of arginine dihydrolase and lysine decarboxylase and inability to utilize citrate, however, differentiated strain $\mathrm{WH} 134^{\top}$ from $\mathrm{V}$. rumoiensis DSM $19141^{\top}$. On the basis of the phenotypic, chemotaxonomic and phylogenetic evidence, strain $\mathrm{WH} 134^{\top}$ represents a novel species of the genus Vibrio, for which the name Vibrio marisflavi sp. nov. is proposed. The type strain is $\mathrm{WH}_{13} 4^{\top}\left(=\mathrm{CGMCC} 1.8994^{\top}=\mathrm{LMG}\right.$ $25284^{\top}=$ DSM $23086^{\top}$ ).
\end{abstract}

Vibrios are typically Gram-negative, motile rods, mesophilic, chemo-organotrophic and have a facultatively fermentative metabolism (Baumann et al., 1984). Microorganisms belonging to the genus Vibrio occur frequently in marine and estuarine waters where they are often found associated with various organisms, ranging from plankton to fish (Thompson et al., 2004). Phenotypic and molecular analyses have shown that members of the genus Vibrio are highly heterogeneous (Thompson et al., 2005). In the last few years, with improvements in the taxonomy of vibrios, there has been a large increase in the number of species assigned to the genus Vibrio (Chang et al., 2008; Gomez-Gil et al., 2008; Rameshkumar et al., 2008; Beaz-Hidalgo et al., 2009; Yoshizawa et al., 2009; Xu et al., 2009; Wang et al., 2010). In the present study, a Vibrio-like bacterial strain, designated $\mathrm{WH}_{134^{\mathrm{T}}}$, recently isolated from seawater samples, was analysed and its exact taxonomic position was determined using a polyphasic approach.

\footnotetext{
Abbreviations: MLSA, multilocus sequence analysis; O/129, 2,4diamino-6,7-diisopropyl-pteridine phosphate salt; PHB, poly- $\beta$-hydroxybutyrate; YSCWM, Yellow Sea Cold Water Mass.

The GenBank/EMBL/DDBJ accession numbers for the $16 \mathrm{~S}$ rRNA, gyr $B$, topA, recA, fts $Z$, mreB, rpo $A$ and gapA gene sequences of strain $\mathrm{WH}_{134^{\top}}$ are FJ847833, GU366192, GU366193, HM036066, HM036067, HM036068, HM036069 and HM036070, respectively.

One supplementary table and nine supplementary figures are available with the online version of this paper.
}

Strain $\mathrm{WH} 134^{\mathrm{T}}$ was isolated from a seawater sample collected at a depth of about $10 \mathrm{~m}$ near the Yellow Sea Cold Water Mass (YSCWM), $31^{\circ} 59.970^{\prime} \mathrm{N} 123^{\circ} 0.157^{\prime} \mathrm{E}$, China, in July 2008. The temperature of the seawater was $20.5{ }^{\circ} \mathrm{C}$ with salinity of $33.2 \mathrm{~g} \mathrm{l}^{-1}$, conductivity of $46.2 \mathrm{~ms} \mathrm{~cm}^{-1}$, density of $1023.3 \mathrm{~kg} \mathrm{~m}{ }^{-3}$, chlorophyll content of 0.32 p.p.b. and turbidity of $1 \mathrm{FTU}$. A semitransparent colony, strain $\mathrm{WH} 134^{\mathrm{T}}$, was isolated on marine 2216E agar (MA; Difco) after incubation at $28{ }^{\circ} \mathrm{C}$ for 2 days and was obtained in pure culture after three successive transfers to fresh MA plates. Working cultures were maintained on $\mathrm{MA}$ at $28{ }^{\circ} \mathrm{C}$ and stocks were kept as cell suspensions at $-80{ }^{\circ} \mathrm{C}$ in sterile $0.9 \%$ $(\mathrm{w} / \mathrm{v})$ saline supplemented with $15 \%(\mathrm{v} / \mathrm{v})$ glycerol.

Standard protocols to determine Gram reaction, catalase and oxidase activities, endospore formation, degradation of casein, starch, gelatin, DNA, Tween 80 and urea, nitrate reduction, hydrogen sulfate production from thiosulfate and 2,4-diamino-6,7-diisopropyl-pteridine phosphate salt $(\mathrm{O} /$ 129) sensitivity were employed (Tindall et al., 2007) using suitably modified MA or marine 2216E broth (MB; Difco). Cell morphology and the presence of flagella were determined using transmission electron microscopy (JEM1200EX; JEOL) after cells of strain $\mathrm{WH} 134^{\mathrm{T}}$ had been negatively stained with $1 \%(\mathrm{w} / \mathrm{v})$ phosphotungstic acid. Nile blue $\mathrm{A}$ was used as a fluorescent stain to test cells for poly- $\beta$ hydroxybutyrate $(\mathrm{PHB})$ accumulation under a fluorescence microscope (BH2; Olympus) (Ostle \& Holt, 1982). Growth was tested on thiosulfate-citrate-bile salts sucrose (TCBS) 
agar (Difco) and tryptone soy agar (TSA; Difco) supplemented with $2 \%(\mathrm{w} / \mathrm{v}) \mathrm{NaCl}$ for $48 \mathrm{~h}$ at $28{ }^{\circ} \mathrm{C}$. Swarming motility was tested on tryptone agar (1\% tryptone, $1.5 \%$ $\mathrm{NaCl}$ and $0.6 \%$ agar). Growth under anaerobic conditions was determined by incubation on MA for 5 days at $28{ }^{\circ} \mathrm{C}$ in a dry cylinder containing $10 \mathrm{~g}$ gallic acid and $100 \mathrm{ml} 10 \%$ $\mathrm{NaOH}$ reacting to consume oxygen. The temperature range for growth was determined on MA plates by incubating cultures at $4-40{ }^{\circ} \mathrm{C}$ for 10 days (Tindall et al., 2007). Halotolerance was investigated using synthetic marine ZoBell broth comprising $5 \mathrm{~g}$ Bacto peptone, $1 \mathrm{~g}$ yeast extract and $0.1 \mathrm{~g} \mathrm{FePO}_{4}$ in 11 modified artificial seawater (Lyman \& Fleming, 1940) supplied with 0-15\% (w/v) NaCl. In the modified artificial seawater, all of the $\mathrm{Na}^{+}$was replaced by $\mathrm{K}^{+}$. Growth at $\mathrm{pH} 4-11$ (increments of $1 \mathrm{pH}$ unit) was determined by measuring changes in $\mathrm{OD}_{600}$ over time in MB buffered with citrate/phosphate $\left(0.2 \mathrm{~mol} \mathrm{l}^{-1}\right)$, Tris/ $\mathrm{HCl}\left(0.05 \mathrm{~mol} \mathrm{l}^{-1}\right)$ or $\mathrm{Na}_{2} \mathrm{CO}_{3} / \mathrm{NaOH}\left(0.025 \mathrm{~mol} \mathrm{l}^{-1}\right)$ (Breznak \& Costilow, 1994). Susceptibility to antibiotics was investigated on MA plates by using discs containing different antibiotics. Other phenotypic and enzymic properties of strain $\mathrm{WH} 134^{\mathrm{T}}$ were tested using API $20 \mathrm{E}$, API $20 \mathrm{NE}$, API $50 \mathrm{CH}$ and API ZYM test strips (bioMérieux) and Gramnegative MicroPlates (Biolog) with incubation at $28{ }^{\circ} \mathrm{C}$ according to the manufacturer's instructions, except that sterile $1.5 \%(\mathrm{w} / \mathrm{v}) \mathrm{NaCl}$ was used to prepare the inocula. Vibrio rumoiensis DSM $19141^{\mathrm{T}}$ was obtained from DSMZ (Germany) and used as a reference strain.

For fatty acid methyl ester analysis, cells of strain $\mathrm{WH} 134^{\mathrm{T}}$ and V. rumoiensis DSM $19141^{\mathrm{T}}$ were harvested from MB after incubation at $28{ }^{\circ} \mathrm{C}$ for $48 \mathrm{~h}$ and the fatty acid profiles were determined as described previously (Xie \& Yokota, 2003) using the Sherlock microbial identification system (MIDI). The $\mathrm{G}+\mathrm{C}$ content of the genomic DNA was determined according to the methods described by Mesbah \& Whitman (1989) using reverse-phase HPLC.

For 16S rRNA gene sequencing, DNA was extracted from strain $\mathrm{WH} 134^{\mathrm{T}}$, purified by standard methods (Ausubel et al., 1995) and amplified by PCR using the universal primers 27F (5' -AGAGTTTGATCCTGGCTCAG-3') and 1492R (5' GGTTACCTTGTTACGACTT- ${ }^{\prime}$ ). Multilocus sequence analysis (MLSA) based on partial sequences of seven housekeeping genes encoding DNA gyrase B subunit $(g y r B)$, topoisomerase I (topA), a recombination repair protein $(r e c A)$, a cell division protein $(f t s Z)$, rod shaping protein B subunit (mreB), glyceraldehyde 3-phosphate dehydrogenase (gapA) and RNA polymerase alpha-subunit $(r p o A)$ was used for further identification and classification of strain $\mathrm{WH} 134^{\mathrm{T}}$. PCR primer sequences were obtained from Sawabe et al. (2007) for the topA, recA, ftsZ, mreB and gapA genes, from Yamamoto et al. (1999) for the gyrB gene and from Thompson et al. (2005) for the rpoA gene. The PCR products were purified using a TaKaRa agarose gel DNA purification kit (TaKaRa Biotechnology). The purified products were sequenced by Shanghai Biosune (China) with an Applied Biosystems automatic sequencer (ABI3730).
The 16S rRNA and seven housekeeping gene sequences were aligned and compared with available sequences in the GenBank/EMBL/DDBJ databases using BLAST searches and the 16S rRNA gene sequence was also compared with those in the EzTaxon database (http://www.eztaxon.org/) (Chun et al., 2007). Phylogenetic analyses based on the individual and concatenated sequences were performed using the software package MEGA version 4.0 (Tamura et al., 2007) after the multiple alignment of data by CLUSTAL_X (Thompson et al., 1997). 16S rRNA gene sequence similarities between $\mathrm{WH} 134^{\mathrm{T}}$ and other species of the genus Vibrio were calculated using the program PHYDIT (http:// plaza.snu.ac.kr/ jchun/phydit) and the EzTaxon public database (Chun et al., 2007). Phylogenetic trees were reconstructed using the neighbour-joining and maximum-parsimony methods using the Kimura 2-state parameter model implemented in MEGA version 4.0 (Tamura et al., 2007).

Detailed morphological, physiological and biochemical characteristics of strain $\mathrm{WH} 134^{\mathrm{T}}$ are given in the species description and in Table 1 and transmission electron micrographs of strain $\mathrm{WH}_{134^{\mathrm{T}}}$ are presented in Supplementary Fig. S1 (available in IJSEM Online). Cells of strain $\mathrm{WH} 134^{\mathrm{T}}$ were Gram-reaction-negative, slightly curved, $0.4-0.6 \times 0.8-1 \mu \mathrm{m}$ with a single polar flagellum and were facultatively anaerobic based on observations of growth in both aerobic and anaerobic conditions. Growth occurred in 1-6\% (w/v) NaCl, while no growth occurred in the absence of $\mathrm{NaCl}$. Based on this phenotypic evidence, strain $\mathrm{WH} 134^{\mathrm{T}}$ was clearly assigned to the genus Vibrio (Baumann et al., 1984) but could be differentiated from its closest relative $V$. rumoiensis DSM $19141^{\mathrm{T}}$ by the possession of a flagellum, arginine dihydrolase and lysine decarboxylase activities and the inability to utilize citrate. Strain $\mathrm{WH} 134^{\mathrm{T}}$ could also be clearly differentiated from other closely related Vibrio species in tests for lysine decarboxylase activity, acid production from melibiose and D-mannitol and the utilization of gentiobiose, myoinositol, raffinose and turanose as sole carbon and energy sources (Table 1). Other characteristics that differentiated strain $\mathrm{WH} 134^{\mathrm{T}}$ from members of closely related species of the genus Vibrio are shown in Table 1.

The major fatty acid composition of strain $\mathrm{WH} 134^{\mathrm{T}}$ was as follows: summed feature 3 comprising $\mathrm{C}_{16: 1} \omega 7 c$ and/or iso$\mathrm{C}_{15: 0} 2-\mathrm{OH}(30.3 \%), \mathrm{C}_{16: 0}(30.1 \%), \mathrm{C}_{18: 1} \omega 7 c(16.7 \%)$, $\mathrm{C}_{18: 0}(5.3 \%), \mathrm{C}_{14: 0}(5.3 \%), \mathrm{C}_{12: 0} 3-\mathrm{OH}(2.9 \%), \mathrm{C}_{12: 0}$ $(2.6 \%)$ and summed feature 2 comprising $\mathrm{C}_{14: 0} 3-\mathrm{OH}$ and/ or iso- $\mathrm{C}_{16: 1} \mathrm{I}(1.2 \%)$ (Table 2$)$. The fatty acid profile of strain $\mathrm{WH} 134^{\mathrm{T}}$ was similar to that of other members of the genus Vibrio but showed a distinct pattern from type strains of the closest phylogenetically related species. The quantities of fatty acids of summed feature 3 comprising $\mathrm{C}_{16: 1} \omega 7 \mathrm{c}$ and/ or iso- $\mathrm{C}_{15: 0} 2-\mathrm{OH}$ were much lower, and the quantities of fatty acids $\mathrm{C}_{16: 0}$ and $\mathrm{C}_{18: 0}$ were much higher, in strain $\mathrm{WH} 134^{\mathrm{T}}$ than in $V$. rumoiensis DSM $19141^{\mathrm{T}}, V$. gigantis DSM $18531^{\mathrm{T}}, V$. pomeroyi LMG $20537^{\mathrm{T}}$ and $V$. litoralis KCTC $12520^{\mathrm{T}}$ (Table 2). For other fatty acids, no clear 
Table 1. Differential characteristics of strain $\mathrm{WH} 134^{\top}$ and closely related species of the genus Vibrio

Taxa: 1, WH134 ${ }^{\mathrm{T}}$; 2, V. rumoiensis DSM $19141^{\mathrm{T}}$ (data from this study); 3, V. gigantis DSM $18531^{\mathrm{T}}$ (Le Roux et al., 2005; Noguerola \& Blanch, 2008); 4, V. pomeroyi LMG $20537^{\mathrm{T}}$ (Thompson et al., 2003; Noguerola \& Blanch, 2008); 5, V. gallaecicus LMG $24045^{\mathrm{T}}$ (Beaz-Hidalgo et al., 2009); 6, V. litoralis MANO22 $\mathrm{D}^{\mathrm{T}}$ (Nam et al., 2007; Noguerola \& Blanch, 2008); 7, V. proteolyticus ATCC $15338^{\mathrm{T}}$ (Noguerola \& Blanch, 2008). From repeat experiments: + , positive for $\geqslant 90 \%$; $(+)$, positive for $75-89 \%$; - , negative for $\leqslant 10 \%$; $v$, variable for $26-74 \%$; ND, no data available. All taxa were negative for luminescence and acid production from D-sorbitol and L-rhamnose and were positive for nitrate reduction and oxidase and catalase activities.

\begin{tabular}{|c|c|c|c|c|c|c|c|}
\hline Characteristic & 1 & 2 & 3 & 4 & 5 & 6 & 7 \\
\hline Arginine dihydrolase & + & - & + & + & - & - & + \\
\hline Lysine decarboxylase & + & - & - & - & - & ND & + \\
\hline Ornithine decarboxylase & - & - & - & - & - & ND & - \\
\hline Gelatinase & + & - & + & + & + & - & $\mathrm{V}$ \\
\hline Flagella & + & - & + & + & + & + & + \\
\hline Swarming motility & - & - & - & - & - & $\mathrm{ND}$ & + \\
\hline$\beta$-Galactosidase & + & - & - & + & - & - & + \\
\hline Indole production & - & - & $\mathrm{ND}$ & + & - & - & + \\
\hline Citrate utilization & - & + & ND & - & - & + & + \\
\hline Voges-Proskauer & - & - & - & - & - & $\mathrm{ND}$ & $(+)$ \\
\hline \multicolumn{8}{|l|}{ Susceptibility to: } \\
\hline $\mathrm{O} / 129(150 \mu \mathrm{g})$ & - & - & - & - & + & - & $\mathrm{V}$ \\
\hline Ampicillin & - & - & ND & + & - & ND & - \\
\hline \multicolumn{8}{|l|}{ Growth at/in: } \\
\hline $4{ }^{\circ} \mathrm{C}$ & - & + & + & + & + & + & - \\
\hline $37^{\circ} \mathrm{C}$ & + & - & - & - & - & + & + \\
\hline $1 \% \mathrm{NaCl}$ & + & + & + & + & + & + & + \\
\hline $8 \% \mathrm{NaCl}$ & - & + & - & + & - & + & + \\
\hline \multicolumn{8}{|l|}{ Acid produced from: } \\
\hline D-Mannitol & - & + & + & + & + & + & + \\
\hline Melibiose & + & - & - & - & - & $\mathrm{ND}$ & - \\
\hline L-Arabinose & - & + & - & - & - & + & - \\
\hline \multicolumn{8}{|l|}{ Utilization of: } \\
\hline Glycogen & - & + & + & + & ND & - & ND \\
\hline L-Arabinose & - & + & - & ND & ND & + & - \\
\hline D-Arabitol & - & + & - & - & ND & + & ND \\
\hline myo-Inositol & + & - & - & - & $\mathrm{ND}$ & $\mathrm{ND}$ & - \\
\hline D-Mannitol & - & + & + & ND & ND & + & + \\
\hline
\end{tabular}

differences were observed between strain $\mathrm{WH} 134^{\mathrm{T}}$ and type strains of related species of the genus Vibrio (Table 2). The DNA G + C content of strain $\mathrm{WH} 134^{\mathrm{T}}$ was $42.5 \mathrm{~mol} \%$, which was well within the range of 38-51 mol\% typical of the genus Vibrio (Farmer et al., 2005).

Searches using the almost-complete $16 \mathrm{~S}$ rRNA gene sequence $(1290 \mathrm{bp})$ of strain $\mathrm{WH} 134^{\mathrm{T}}$ in the NCBI GenBank and EzTaxon databases placed it among members of the genus Vibrio. However, 16S rRNA gene sequence similarities between strain $\mathrm{WH} 134^{\mathrm{T}}$ and recognized species of the genus Vibrio were not greater than $97 \%$; the highest similarity being to $V$. rumoiensis S- $1^{\mathrm{T}}(96.6 \%)$. The $16 \mathrm{~S}$ rRNA gene sequence-based neighbour-joining (Fig. 1) and
Table 2. Cellular fatty acid content (\%) of strain $\mathrm{WH} 134^{\top}$ and closely related species of the genus Vibrio

Taxa: 1, strain WH134 ${ }^{\mathrm{T}} ; 2$, V. rumoiensis DSM $19141^{\mathrm{T}}$ (data from this study); 3, V. gigantis DSM $18531^{\mathrm{T}}$ (Le Roux et al., 2005); 4, V. pomeroyi LMG $20537^{\mathrm{T}}$ (Thompson et al., 2003); 5, V. litoralis KCTC $12520^{\mathrm{T}}$ (Nam et al., 2007). - , Not detected or detected in trace amounts $<1 \%$.

\begin{tabular}{|c|c|c|c|c|c|}
\hline Fatty acid & 1 & 2 & 3 & 4 & 5 \\
\hline \multicolumn{6}{|c|}{ Straight-chain fatty acids } \\
\hline $\mathrm{C}_{12: 0}$ & 2.6 & 3.5 & 4.5 & 8.9 & 3.7 \\
\hline $\mathrm{C}_{14: 0}$ & 5.3 & 3.3 & 4.7 & 10.5 & - \\
\hline iso- $\mathrm{C}_{15: 0}$ & 1.2 & - & - & - & - \\
\hline $\mathrm{C}_{16: 0}$ & 30.1 & 21.1 & 23.5 & 29.2 & 13.5 \\
\hline iso- $\mathrm{C}_{16: 0}$ & - & - & 2.4 & - & - \\
\hline iso- $\mathrm{C}_{17: 0}$ & 1.2 & - & - & - & - \\
\hline $\mathrm{C}_{18: 0}$ & 5.3 & 4.1 & - & 1.6 & - \\
\hline \multicolumn{6}{|c|}{ Unsaturated fatty acids } \\
\hline $\mathrm{C}_{18: 1} \omega 7 c$ & 16.7 & 17.0 & 12.5 & 7.6 & 19.5 \\
\hline $\mathrm{C}_{18: 1} \omega 9 c$ & - & 1.3 & - & - & - \\
\hline \multicolumn{6}{|c|}{ Hydroxy fatty acids } \\
\hline $\mathrm{C}_{12: 0} 3-\mathrm{OH}$ & 2.9 & - & 1.9 & 3.9 & - \\
\hline \multicolumn{6}{|c|}{ Summed features ${ }^{\star}$} \\
\hline 2 & 1.2 & 5.1 & 2.3 & 4.1 & 7.1 \\
\hline 3 & 30.3 & 42.9 & 40.4 & 32.9 & 38.6 \\
\hline
\end{tabular}

${ }^{*}$ Summed features are groups of two or three fatty acids that cannot be separated by GLC with the MIDI system. Summed feature 2 comprises $\mathrm{C} 14: 0$ 3-OH and/or iso-C16:1 I. Summed feature 3 comprises $\mathrm{C} 16: 1 \omega 7 c$ and/or iso-C15:0 2-OH.

maximum-parsimony (Supplementary Fig. S2) trees showed that strain $\mathrm{WH} 134^{\mathrm{T}}$ formed a cluster with $V$. rumoiensis $\mathrm{S}-1^{\mathrm{T}}$ and $V$. litoralis $\mathrm{MANO} 22 \mathrm{D}^{\mathrm{T}}$ within the radiation including members of the genus Vibrio.

MLSA has proven to be a valuable technique for the identification of vibrios, as well as for studying the phylogeny of the genus (Thompson et al., 2005). Neighbour-joining trees based on gyrB (1259 bp), recA (500 bp), ftsZ (444 bp), gapA (683 bp) and rpoA (600 bp) gene sequences aligned by CLUSTAL_X showed that strain WH134 ${ }^{\mathrm{T}}$ formed a clade on its own, the tree based on topA (414 bp) gene sequences showed that strain $\mathrm{WH} 134^{\mathrm{T}}$ formed a cluster with Vibrio xuii LMG $21346^{\mathrm{T}}$ and the tree based on $m r e B(507 \mathrm{bp})$ gene sequences showed that strain $\mathrm{WH}_{13}{ }^{\mathrm{T}}$ formed a cluster with $V$. rumoiensis DSM $19141^{\mathrm{T}}$ (Supplementary Figs S3-S9). The gyrB, topA, recA, fts $Z$, mreB, gapA and $r p o A$ gene sequence similarities between strain $\mathrm{WH} 134^{\mathrm{T}}$ and $V$. rumoiensis DSM $19141^{\mathrm{T}}$ were $75.7,74.6,83.6,78.9,82.9,86.0$ and $89.4 \%$, respectively. The neighbour-joining phylogenetic tree (Fig. 2) based on concatenated sequences of the seven housekeeping genes (gyrB, topA, recA, fts $Z$, mreB, gapA and rpoA) confirmed that strain $\mathrm{WH} 134^{\mathrm{T}}$ had a close evolutionary distance from $V$. rumoiensis DSM $19141^{\mathrm{T}}$ supported by an elevated bootstrap value. The GenBank accession numbers for the gyrB, topA, recA, fts $Z$, mreB, gapA and rpoA gene sequences used for 


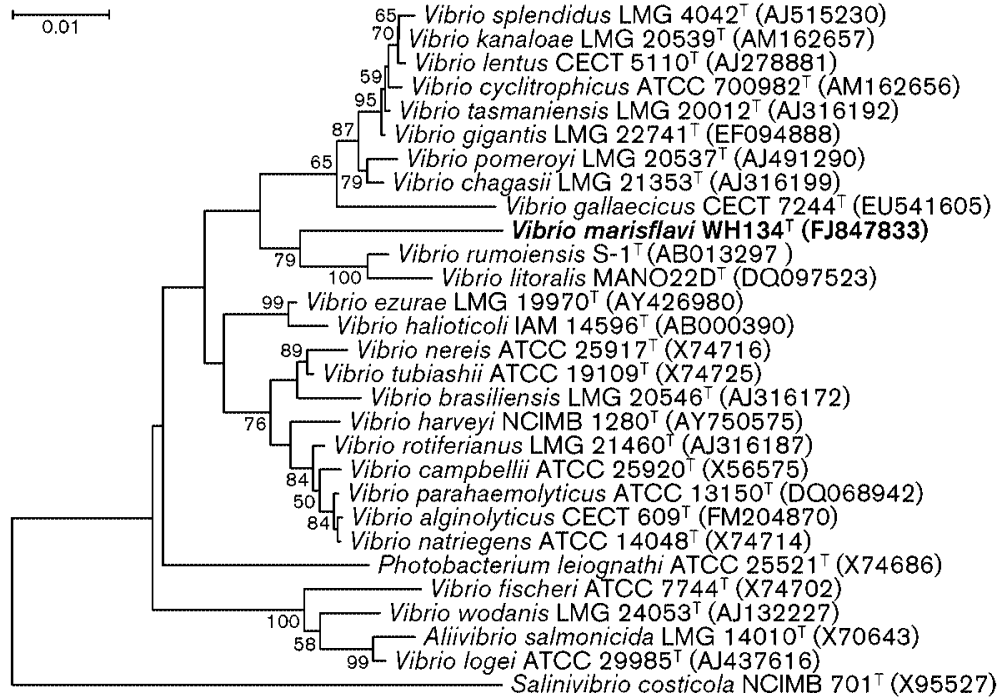

Fig. 1. Phylogenetic tree based on $16 \mathrm{~S}$ rRNA gene sequences of strain $\mathrm{WH} 134^{\top}$ and related members of the genus Vibrio and reconstructed using the neighbour-joining method. Bootstrap values $>50 \%$ (based on 1000 replicates) are given at branching points. GenBank sequence accession numbers are given in parentheses. Bar, 0.01 substitutions per nucleotide position. reconstructing phylogenetic trees are listed in Supplementary Table S1.

Based on the phenotypic characterization and phylogenetic analysis, strain $\mathrm{WH} 134^{\mathrm{T}}$ represents a novel species of the genus Vibrio, for which the name Vibrio marisflavi sp. nov. is proposed.

\section{Description of Vibrio marisflavi sp. nov.}

Vibrio marisflavi (ma.ris.fla'vi. L. n. mare -is the sea; L. adj. flavus - a -um yellow; N.L. gen. n. marisflavi of the Yellow Sea, isolated from the Yellow Sea Cold Water Mass).

Cells are Gram-reaction-negative, slightly curved rods, 0.4$0.6 \times 0.8-1 \mu \mathrm{m}$, facultatively anaerobic and motile by means of a polar flagellum. Swarming motility and bioluminescence are not detected. Colonies on MA media are light-yellow, $1-1.5 \mathrm{~mm}$ in diameter, smooth and

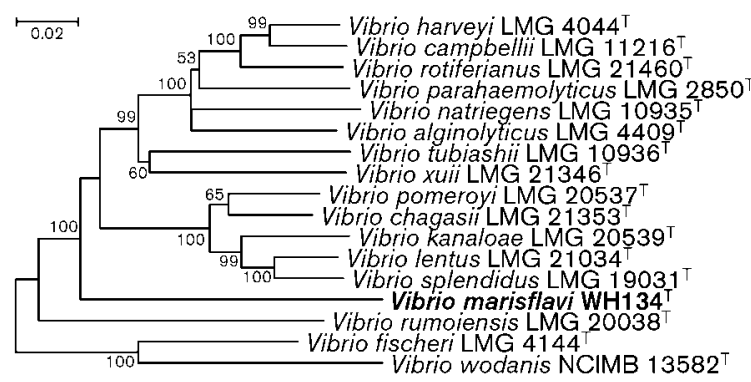

Fig. 2. Phylogenetic tree based on concatenated sequences of seven gene loci, including $\operatorname{gr} B$ (1259 bp), top $A$ (414 bp), rec $A$ (500 bp), ftsZ (444 bp), mreB (507 bp), rpoA (600 bp) and gap $A$ (683 bp), and reconstructed using the neighbour-joining method. Bootstrap values $>50 \%$ (based on 1000 replicates) are given at branching points. GenBank sequence accession numbers for the individual genes are available in Supplementary Table S1. Bar, 0.02 substitutions per nucleotide position. circular. Grows on TSA and forms yellow, translucent colonies on TCBS agar. Accumulation of PHB inside the cells is observed. Voges-Proskauer reaction is negative. Catalase and oxidase activities are weakly positive. Tests for gelatinase, caseinase, DNase, lipase, arginine dihydrolase, lysine decarboxylase and $\beta$-galactosidase activities and hydrolysis of aesculin are positive but tests for amylase, urease, tryptophan deaminase and ornithine decarboxylase activities, citrate utilization and indole and hydrogen sulfide production are negative. Nitrate is reduced to nitrite. Growth occurs at $16-37{ }^{\circ} \mathrm{C}$, but not at 4 or $40{ }^{\circ} \mathrm{C}$, at $\mathrm{pH} 5-10$ and in $1-6 \%(\mathrm{w} / \mathrm{v}) \mathrm{NaCl}$, but not in the absence of $\mathrm{NaCl}$. In the API $50 \mathrm{CH}$ system, acid is produced from D-glucose, sucrose, melibiose, amygdalin, glycerol, Dribose, D-xylose, D-galactose, D-fructose, methyl $\alpha$-Dglucopyranoside, $N$-acetylglucosamine, arbutin, D-mannose, aesculin, salicin, cellobiose, maltose, trehalose, gentiobiose and potassium gluconate but not from the other carbon sources on the test strips. In the API ZYM system, positive for alkaline phosphatase, esterase (C4), esterase lipase (C8), leucine arylamidase, acid phosphatase and naphthol-AS-B1-phosphohydrolase but negative for lipase (C14), valine arylamidase, cystine arylamidase, trypsin, $\alpha$-chymotrypsin, $\alpha$-galactosidase, $\beta$-glucuronidase, $\alpha$-glucosidase, $\beta$-glucosidase, $N$-acetyl- $\beta$-glucosaminidase, $\alpha$-mannosidase and $\alpha$-fucosidase activities. In MicroPlates (Biolog), the following substrates are utilized as sole carbon and energy sources: Tweens 40 and 80, N-acetyl-Dgalactosamine, $N$-acetyl-D-glucosamine, cellobiose, Dfructose, D-galactose, gentiobiose, $\alpha$-D-glucose, myo-inositol, maltose, D-mannose, melibiose, D-psicose, raffinose, sucrose, trehalose, turanose, methyl pyruvate, acetic acid, cis-aconitic acid, citric acid, D-gluconic acid, succinic acid, bromosuccinic acid, L-alanine, L-alanyl glycine, L-asparagine, L-aspartic acid, L-glutamic acid, glycyl L-aspartic acid, glycyl L-glutamic acid, L-histidine, L-serine, L-threonine, urocanic acid, inosine, uridine, glycerol, $\alpha$-DL-glycerol phosphate and glucose 6-phosphate; other substrates on 
the test strips are not utilized. Resistant to ( $\mu \mathrm{g}$ per disc unless stated otherwise) vancomycin (30), clindamycin (2), amikacin (30), gentamicin (10), kanamycin (30), neomycin (30), chloromycetin (30), minocycline (30), doxycycline (30), oxacillin sodium (1), ampicillin (10), cephalothin IV (30), cephalothin V (30) and Fortum (30), but sensitive to midecamycin (30), norfloxacin (10), ofloxacin (5), ciprofloxacin (5), polymyxin B (100 U), compound sulfamethoxazole (75), furazolidone (300), chloramphenicol (30), piperacillin (100) and cephalothin VI (30). The predominant cellular fatty acids are summed feature 3 $\left(\mathrm{C}_{16: 1} \omega 7 c\right.$ and/or iso- $\left.\mathrm{C}_{15: 0} 2-\mathrm{OH}\right), \mathrm{C}_{16: 0}, \mathrm{C}_{18: 1} \omega 7 c, \mathrm{C}_{18: 0}$, $\mathrm{C}_{14: 0}, \mathrm{C}_{12: 0} 3-\mathrm{OH}, \mathrm{C}_{12: 0}$, summed feature $2\left(\mathrm{C}_{14: 0} 3-\mathrm{OH}\right.$ and/or iso- $\mathrm{C}_{16: 1} \mathrm{I}$ ), iso- $\mathrm{C}_{17: 0}$ and iso- $\mathrm{C}_{15: 0}$.

The type strain, $\mathrm{WH} 134^{\mathrm{T}}$ (=CGMCC $1.8994^{\mathrm{T}}=\mathrm{LMG}$ $25284^{\mathrm{T}}=\mathrm{DSM} 23086^{\mathrm{T}}$ ), was isolated from seawater samples collected near the Yellow Sea Cold Water Mass $\left(31^{\circ} 59.970^{\prime} \mathrm{N} 123^{\circ} 0.157^{\prime} \mathrm{E}\right)$, China. The DNA G+C content of the type strain is $42.5 \mathrm{~mol} \%$.

\section{Acknowledgements}

This work was supported by the National High Technology R\&D Program of China (no. 2007AA09Z434), the National Natural Science Foundation of China (no. 40876067), and a grant from the Major State Basic R\&D Program of China (no. 2006CB101803).

\section{References}

Ausubel, F. M., Brent, R., Kingston, R. E., Moore, D. D., Seidman, J. G., Smith, J. A. \& Struhl, K. (editors) (1995). Short Protocols in Molecular Biology: a Compendium of Methods from Current Protocols in Molecular Biology, 3rd edn. New York: Wiley.

Baumann, P., Furniss, A. L. \& Lee, J. V. (1984). Genus I. Vibrio Pacine 1854. In Bergey's Manual of Systematic Bacteriology, pp. 518-538. Edited by N. R. Krieg \& J. G. Holt. Baltimore: Williams \& Wilkins.

Beaz-Hidalgo, R., Doce, A., Pascual, J., Toranzo, A. E. \& Romalde, J. L. (2009). Vibrio gallaecicus sp. nov. isolated from cultured clams in north-western Spain. Syst Appl Microbiol 32, 111-117.

Breznak, J. A. \& Costilow, R. N. (1994). Physicochemical factors in growth. In Methods for General and Molecular Bacteriology, pp. 137154. Edited by P. Gerhardt, R. G. E. Murray, W. A. Wood \& N. R. Krieg. Washington, DC: American Society for Microbiology.

Chang, H. W., Roh, S. W., Kim, K. H., Nam, Y. D., Jeon, C. O., Oh, H. M. \& Bae, J. W. (2008). Vibrio areninigrae sp. nov., a marine bacterium isolated from black sand. Int J Syst Evol Microbiol 58, 1903-1906.

Chun, J., Lee, J.-H., Jung, Y., Kim, M., Kim, S., Kim, B. K. \& Lim, Y. W. (2007). EzTaxon: a web-based tool for the identification of prokaryotes based on $16 \mathrm{~S}$ ribosomal RNA gene sequences. Int J Syst Evol Microbiol 57, 2259-2261.

Farmer, J. J., Janda, J. M., Brenner, F. W., Cameron, D. N. \& Birkhead, K. M. (2005). Genus I. Vibrio Pacini $1854,411^{\mathrm{AL}}$. In Bergey's Manual of Systematic Bacteriology, 2nd edn, vol. 2B, pp. 494546. Edited by D. J. Brenner, N. R. Krieg \& J. T. Staley. Baltimore: Williams \& Wilkins.

Gomez-Gil, B., Fajer-Avila, E., Pascual, J., Macián, M. C., Pujalte, M. J., Garay, E. \& Roque, A. (2008). Vibrio sinaloensis sp. nov., isolated from the spotted rose snapper, Lutjanus guttatus Steindachner, 1869. Int J Syst Evol Microbiol 58, 1621-1624.
Le Roux, F., Goubet, A., Thompson, F. L., Faury, N., Gay, M., Swings, J. \& Saulnier, D. (2005). Vibrio gigantis sp. nov., isolated from the haemolymph of cultured oysters (Crassostrea gigas). Int J Syst Evol Microbiol 55, 2251-2255.

Lyman, J. \& Fleming, R. H. (1940). Composition of seawater. J Mar Res 3, 134-146.

Mesbah, M. \& Whitman, W. B. (1989). Measurement of deoxyguanosine/thymidine ratios in complex mixtures by high-performance liquid chromatography for determination of the mole percentage guanine + cytosine of DNA. J Chromatogr A 479, 297306.

Nam, Y. D., Chang, H. W., Park, J. R., Kwon, H. Y., Quan, Z. X., Park, Y. H., Kim, B. C. \& Bae, J. W. (2007). Vibrio litoralis sp. nov., isolated from a Yellow Sea tidal flat in Korea. Int J Syst Evol Microbiol 57, 562 565.

Noguerola, I. \& Blanch, A. R. (2008). Identification of Vibrio spp. with a set of dichotomous keys. J Appl Microbiol 105, 175-185.

Ostle, A. G. \& Holt, J. G. (1982). Nile blue A as a fluorescent stain for poly- $\beta$-hydroxybutyrate. Appl Environ Microbiol 44, 238241.

Rameshkumar, N., Fukui, Y., Sawabe, T. \& Nair, S. (2008). Vibrio porteresiae sp. nov., a diazotrophic bacterium isolated from a mangrove-associated wild rice (Porteresia coarctata Tateoka). Int J Syst Evol Microbiol 58, 1608-1615.

Sawabe, T., Kita-Tsukamoto, K. \& Thompson, F. L. (2007). Inferring the evolutionary history of vibrios by means of multilocus sequence analysis. J Bacteriol 189, 7932-7936.

Tamura, K., Dudley, J., Nei, M. \& Kumar, S. (2007). MEGA4: molecular evolutionary genetics analysis (MEGA) software version 4.0. Mol Biol Evol 24, 1596-1599.

Thompson, J. D., Gibson, T. J., Plewniak, F., Jeanmougin, F. \& Higgins, D. G. (1997). The CLUSTAL_X windows interface: flexible strategies for multiple sequence alignment aided by quality analysis tools. Nucleic Acids Res 25, 4876-4882.

Thompson, F. L., Thompson, C. C., Li, Y., Gomez-Gil, B., Vandenberghe, J., Hoste, B. \& Swings, J. (2003). Vibrio kanaloae sp. nov., Vibrio pomeroyi sp. nov. and Vibrio chagasii sp. nov., from sea water and marine animals. Int J Syst Evol Microbiol 53, 753-759.

Thompson, F. L., lida, T. \& Swings, J. (2004). Biodiversity of vibrios. Microbiol Mol Biol Rev 68, 403-431.

Thompson, F. L., Gevers, D., Thompson, C. C., Dawyndt, P., Naser, S., Hoste, B., Munn, C. B. \& Swings, J. (2005). Phylogeny and molecular identification of vibrios on the basis of multilocus sequence analysis. Appl Environ Microbiol 71, 5107-5115.

Tindall, B. J., Sikorski, J., Smibert, R. M. \& Krieg, N. R. (2007). Phenotypic characterization and the principles of comparative systematics. In Methods for General and Molecular Microbiology, pp. 330-393. Edited by C. A. Reddy, T. J. Beveridge, J. A. Breznak, G. Marzluf, T. M. Schmidt \& L. R. Snyder. Washington, DC: American Society for Microbiology.

Wang, Y., Zhang, X. H., Yu, M., Wang, H. \& Austin, B. (2010). Vibrio atypicus sp. nov., isolated from the digestive tract of the Chinese prawn (Penaeus chinensis O’sbeck). Int J Syst Evol Microbiol 60, 25172523.

Xie, C. H. \& Yokota, A. (2003). Phylogenetic analyses of Lampropedia hyalina based on the 16S rRNA gene sequence. J Gen Appl Microbiol 49, 345-349.

Xu, X. W., Wu, Y. H., Wang, C. S., Oren, A. \& Wu, M. (2009). Vibrio hangzhouensis sp. nov., isolated from sediment of the East China Sea. Int J Syst Evol Microbiol 59, 2099-2103. 
Yamamoto, S., Bouvet, P. J. \& Harayama, S. (1999). Phylogenetic structures of the genus Acinetobacter based on gyrB sequences: comparison with the grouping by DNA-DNA hybridization. Int J Syst Bacteriol 49, 87-95.
Yoshizawa, S., Wada, M., Kita-Tsukamoto, K., Ikemoto, E., Yokota, A. \& Kogure, K. (2009). Vibrio azureus sp. nov., a luminous marine bacterium isolated from seawater. Int J Syst Evol Microbiol 59, 16451649. 